\title{
TANÁRJELÖLTEK REFLEKTÍV NAPLÓI A GYAKORLÓ TANÍTÁSRÓL ${ }^{1}$
}

\author{
SÁNTHA KÁLMÁN
}

a Kodolányi János Főiskola főiskolai docense

skalman@uranos.kodolanyi.hu

$\overline{\text { A tanulmány a tanárjelöltek tanítási gyakorlatával párhuzamosan meghirdetett szeminá- }}$ rium tapasztalatait összegzi: feltárja a reflektiv naplókészités pedagógusképzésben betöltött szerepét, kiemeli a reflektív gondolkodás és a hatékony tanári tevékenység kapcsolatát.

Megszólalt a nagyszünet végét jelző csengő, így az addig vidáman, felszabadultan játszó vagy beszélgető kisdiákok tudták, hogy feladatuk van: fel kell sorakozni a tanterem előtt és meg kell várni a tanárt, hiszen csak az ő engedélyével szabad bemenni a nagy és mindenféle eszközökkel telerakott kémiai, fizikai laboratóriumba. Remélem, hogy ma nem felelek, hiszen a múlt órán már kaptam jegyet - szólt társához az egyik tanuló, és abban bízott, hogy stratégiája megfelelő lesz ahhoz, hogy túlélje az amúgy is borús, ködös napot. Te sokat ne remélj, fiam! - azonnal jött a válasz az éppen érkező pedagógustól, megadva így az alaphangulatot az órához...

A mindennapok iskolai világa által generált különféle pedagógiai szituációk sokaságában a diák és a pedagógus is más és más, időnként pedig hasonló stratégiákkal igyekszik megélni, átélni vagy túlélni (kinek-kinek értelmezése szerint...) a történéseket. Az iskola életének föszereplői vágyakkal, félelmekkel, elvárásokkal lépik át minden reggel az intézmény kapuját, s ezek nagymértékben befolyásolják a tevékenységüket. De vajon hogyan gondolkodnak mindezekröl, miként készülnek, milyen elvárásokkal teszik meg az első lépéseket a tanárjelöltek a pedagóguspályán, azaz hogyan vélekednek a gyakorló tanításról, és a tapasztalataik függvényében miként elemzik saját tevékenységüket?

A tanulmány gondolatmenete két alappillérre épül. Egyrészt célom rámutatni a gyakorló tanítás során szerzett olyan hallgatói tapasztalatokra, ötletekre, érzésekre, amelyek a tanárjelöltek személyes és szakmai fejlődését szolgálják, illetve kiemelt célként fogalmazódik meg a reflektív szemlélet jelentőségének tudatosítása a tanárjelöltek tevékenységében. A reflektív szemlélet tudatosításának lehetségessége, illetve szükségessége tekintetében megoszlanak a vélemények, hiszen többször hallani, hogy a gyakorlat, a rutin úgyis formálja a tanári tevékenységet, így a pályán

\footnotetext{
${ }^{1}$ A tanulmány a Tanárképzés Napja - I. veszprémi konferencián (2008. április 23.) elhangzott előadás szerkesztett, módosított változata.
} 
eltöltött idő függvényében változások tapasztalhatók a pedagógusok mindennapi munkájában. Ez igaz, de nem mindegy, hogy milyen irányúak és milyen mélységüek ezek a változások. A tanári tevékenység ok-okozati összefüggéseinek feltárásához szükséges a tudatos elemzés. Természetesen a gyakorló tanítás időszaka nem alkalmas mindezek hiánytalan kiépítésére, de modellként szolgálhat a reflektív gondolkodás fejlesztésére, így a tanári tevékenység hatékonyabbá tételére is.

Maradva annál az optimista elvnél, hogy a tanárjelöltből pedagógus lesz, nem is olyan távoli célként a tanárjelölteknél megfogalmazható egy olyan elméleti és gyakorlati ismereteket tartalmazó rendszer kifejlesztése is, amely már gyakorló tanárként, a pályán eltöltött idő és a folyamatos reflektálásnak köszönhetően képes lesz átfogni a tanári munka szerteágazó területeit (lásd erről részletesen Kimmel, 2006 tanulmányát).

Honnan származik a gyakorló tanítások elemzésének ötlete? Már több éve, hogy a nappali és levelező tagozatos, végzős tanárjelölt hallgatók számára olyan szemináriumot vezetek, amelynek célja az elméleti pedagógiai ismeretek gyakorlatbeli alkalmazásának elősegítése és a gyakorló tanítás során szerzett tapasztalatok megbeszélése, elemzése. A kurzus párhuzamosan zajlik a gyakorló tanítással, így különösen a nappali tagozatos hallgatók hétről hétre hozhatják iskolai gondjaikat és sikereiket a szemináriumra, amelyeket problémacentrikusan elemzünk. Ekkor a már tanult elméleti ismeretek gyakorlatbeli alkalmazására, illetve az alkalmazás nehézségeire, különféle összefüggéseire is közösen fényt deríthetünk. A tanítás során a hallgatók váltott turnusban általános és középiskolában is végzik gyakorlatukat, így megismerhetik a különbözö korosztályok specifikumait is.

A pedagógusok reflektív gondolkodásának fejlesztésével, a reflektív szemlélet tanári tevékenységben betöltött szerepével már számos hazai pedagógiai szakirodalom foglalkozik (Falus és Kimmel, 2003; Kimmel, 2002, 2006; Sántha, 2007a, 2007b; Szabó, 1999, 2000; Szivák, 2003). A külföldi szakirodalomban megjelennek a reflexió alakjára vonatkozó elképzelések is: Jank és Meyer (2002) a reflexiónak spirális alakot tulajdonítanak, hiszen a pályakezdő és a tapasztalt pedagógusok a visszacsatolásoknak köszönhetően spirálisan építhetik fel tevékenységüket. Hasonlóan gondolkodik Schratz (1998) is, aki körkörös folyamatként értelmezi a reflexiót, ahol múltbeli cselekvésünkre (megtartott óráinkra) reflektálunk azért, hogy a feldolgozatlan negatív élményeinket (ha vannak ilyenek) ne vetítsük a jövőbeni cselekvéseinkre, vagy pedig negatív és pozitív élményeinket feldolgozva legyünk tudatában tevékenységünk minden elemének. Meg kell jegyezni, hogy Schratz a cselekvés utáni reflexió vizsgálatára utal, és nem hangsúlyozza eléggé a cselekvés során megvalósuló reflexió jelentőségét (lásd erről Falus, 2001a, 2001b; Schön, 1983, 1987 írásait).

A tanárjelöltek gyakorló tanítását követő szemináriumon a tapasztalatok öszszegyüjtését a reflektív napló technikájával végezték a hallgatók. Bízom abban, 
hogy a reflektív szemlélet fejlesztése a tanitás tanulásának hatékonyságát fokozhatja, illetve átfogó szakmai fejlődési modell alapját is jelentheti.

A reflektív naplók szabadon választottan, vagy előre megadott, kötött szempontok szerint készíthetők. A szabadon választott naplókészítés technikáját azért nem alkalmaztam, mert a korábbi félévek tapasztalatai szerint az így megírt naplók többsége leíró jellegü volt, egyáltalán nem, vagy csak nagyon kevés elemzést, összefüggést tartalmazott. Ennek okait keresve megállapítható, hogy az egy félév, a reflektív pedagógia alapelveit követő szeminárium esetén kevés a hallgatók reflektív szemléletének fejlesztéséhez, így - segítségként - az előre megadott szempontok szerinti naplókészítést javasoltam a hallgatóknak. De ez a tény már szemléletbeli problémákat is felvet, így célszerü két szempont szerint mérlegelnünk. Először is sokan egyetértenek azzal, hogy a szabadon választott és megfelelően kivitelezett naplók tárják fel igazán az egyéni szemléletet, hiszen az előre megadott szempontok már olyan kutatói elvárást, gondolkodást tükröznek, amelynek a hallgató próbál megfelelni, így irányítottá válhat a feltárás. Másodszor pedig igaz az is, hogy a kötött szempontok szerinti naplózással tehető tudatossá az a gondolkodásmód, amely a saját tevékenység elemzéséhez vezethet.

A feladat az volt, hogy a hallgatóknak öt egymást követő, lehetőleg egy témában, egy osztályban megtartott saját órát kellett elemezni a megadott szempontok alapján. Fontos megjegyezni, hogy ezt a feltételt sem sikerült minden esetben megtartani, hiszen kevés olyan hallgató volt, akinél folyamatában lehetett vizsgálni a gyakorló tanítást. Gyakran előfordult, hogy több napi kimaradás után tanított ugyanabban az osztályban, az így elkészített naplók a reflektív szemlélet vizsgálata szempontjából kevésbé relevánsak, hiszen megszakad a folyamat, lehetetlenné válik például a reflexió spirális formájának átlátása is.

A meghatározott feltételeknek végül 14 végzős hallgató naplója tett eleget. A tanárjelölteket a hozzáférésen alapuló kényelmi kvalitatív mintavétellel választottam ki, hiszen a könnyen és gyorsan elérhető személyekre (a saját csoportom hallgatóira) koncentráltam, de mindig szem előtt tartottam azt, hogy válogatás nélkül ne kerüljön be bárki a mintába (lásd az előre kijelölt szempontok teljesülését). Szükséges hangsúlyozni, hogy kvalitatív elemzésről van szó, amely az egyéni reflektív gondolkodás feltárását és fejlesztését tekinti alapfeladatának, nem törekszik reprezentativitásra. Mivel a korábbi félévekben más tantárgyakat is oktattam szeminárium keretében ugyanezen hallgatók számára, így ismertük egymást, mellérendelö viszonyban, partnerként tekintettünk egymásra, ami garanciát jelentett az építő etikai modell müködésére és arra, hogy a hallgatók feltárnak (elmondanak, leírnak) minden olyan esetet, ami számukra problémát jelent. Mindezekben megerősítenek a szemináriumi munkák és a hallgatói visszajelzések is. A mühelymunka akkor válik igazán hatékonnyá, ha a hozott és a naplókból kiderülő gyakorlati problémákat is megbeszéljük a csoporttal, amely igényli ezt a fajta beszélgetést.

A hallgatók a következő szempontokat kapták a naplók elkészítéséhez: 
Írja le tapasztalatait öt egymást követő, lehetőleg ugyanabban a témában és osztályban tartott órájáról!

Írja le:

- Mit és miért szeretett volna tenni az órán?

- Honnan tudja, hogy így kellett tennie?

- Mi történt ténylegesen?

- Hogy érez a történtekkel kapcsolatban, mit gondol, miért alakulhatott így az óra?

- Milyen más módon tartaná meg legközelebb az órát?

A lépéseket ismételje meg minden óra után!

A naplók feldolgozása tartalomelemzéssel történt. A megadott szempontok már előrevetítenek egyfajta kategorizálást, hiszen a kérdéseknek megfelelően strukturálhatók a leírások. A főbb tartalmi csomópontok a következők voltak:

- A tanári pályára és a tanítási gyakorlatra vonatkozó reflexiók;

- Az osztály viselkedésének hatása a tanítási órára;

- Az első óra és megpróbáltatásai;

- A tanárjelölt tevékenységének elemzése (módszertani, értékelési dilemmák stb.);

- A vezetőtanár, a mentor szerepe.

Minden esetben a jelzett tartalmi kategóriákhoz tartozóan számos alkategória és összefüggéseik gazdagítják az elemzést, de a következőkben a munka jellege és a terjedelmi korlátok miatt csak átfogóan, a legérdekesebbnek és tanulságosnak vélt mozzanatokat emelem ki. Ahol lehet, hangsúlyozom a pozitívumok és a negatívumok megjelenését is.

Az 1. táblázat idézetei alapján látható, hogy több hallgatónál a tanítási gyakorlat megítélése az osztályok viselkedésének függvényében történt, azaz sikereik és kudarcaik legfőbb okának az osztályok magatartását jelölték. Tehát a hallgatók az e kategóriához tartozó reflexiók domináns elemévé a fegyelmezés és a fegyelem problematikáját emelték. Ebben a tekintetben két szempontot célszerü figyelembe venni: a fegyelmezés és a vele járó tanári tevékenység a cél és eszköz pólusok által meghatározott. Vagyis ki az, aki célként értelmezi a fegyelmet az osztályban (a tanári tevékenysége során az a cél, hogy a tanulók csendben, fegyelmezetten dolgozzanak), illetve ki az, aki eszközként tekint a fegyelemre a munkája során (a tevékenysége során a tanulók érdeklődésére alapozva, változatos módszertani kultúrával halad a tananyaggal). A hasonló nézeteket valló hallgatók eltérően értelmezték a munkazaj és a csend fogalmakat is, így teljesen más tanítási stílust preferáltak. Nézetrendszerükben markáns ellentét tapasztalható a hozott, tanulóként átélt, illetve a képzés során szerzett információkkal kapcsolatban. 
1. táblázat: Siker és kudarc a tanítási gyakorlat során

\begin{tabular}{|l|l|}
\hline \multicolumn{1}{|c|}{ Siker } & \multicolumn{1}{c|}{ Kudarc } \\
\hline $\begin{array}{l}\text { „Ez a gyakorlat nem volt olyan borzalmas, } \\
\text { mint amire számítottam. Csak a túlélésben } \\
\text { reménykedtem, de ennek ellenére } \\
\text { kifejezetten élveztem a tanítást.” }\end{array}$ & $\begin{array}{l}\text { „A gyakorlat rettenetesen nehéz volt, } \\
\text { sokszor kiábrándultam a tanitásból. } \\
\text { Az itt eltöltött hetek alatt semmilyen } \\
\text { fejlödést nem tapasztaltam sem a magam, } \\
\text { sem az osztály részéröl.” }\end{array}$ \\
\hline $\begin{array}{l}\text { „Nagyon élveztem a gyerekekkel való } \\
\text { munkát. Úgy tünt a reakciókból, hogy } \\
\text { ôk is.” }\end{array}$ & $\begin{array}{l}\text { „Lelkesedésem már az első hospitálás } \\
\text { alkalmával alábbhagyott. A gyerekeket } \\
\text { alapvetöen semmi sem érdekli, és } \\
\text { a viselkedésük minősíthetetlen.” } \\
\text { Nem hiszem, hogy ezt hosszabb ideig }\end{array}$ \\
\hline
\end{tabular}

A 2. táblázat hűen tükrözi a tanárjelöltek első tanítási napjukra, órájukra vonatkozó pozitív és kevésbé kellemes gondolatokat. A naplókból kiderült, hogy a hallgatók óriási izgalommal várták, hogy megszólaljon a csengő, és el kelljen indulniuk az ebben a pillanatban végtelenül hosszúnak tünő folyóson az osztályterembe, ahol csak fokozódott az izgalom. Mindenki törekedett arra, hogy már a kezdetektől elfogadtassa magát az osztállyal, abban bízva, hogy ez lényegesen megkönnyíti a további munkát. A tanárjelöltek az ,arany középút” megtalálásával próbálták azt a mindkét fél számára elfogadható tanítási-tanulási környezetet megteremteni, amely számukra az oly fontos sikerélmény megszerzésének első lépcsőfoka lehet.

2. táblázat: Az első óra

\begin{tabular}{|l|l|}
\hline Izgalom & $\begin{array}{l}\text {,Annyira izgultam, hogy nagyon gyorsan beszéltem és a gyerekek kicsit } \\
\text { furán néztek rám.” } \\
\text { „Ez volt az első tanított órám, ráadásul dupla óra, végtelenül izgatott } \\
\text { voltam.” } \\
\text {,Eszméletlen furcsa érzés volt /.../ elkezdtem tartani az órát, és mintha } \\
\text { elsötétült volna elöttük minden /.../ nem értem, miért változott az arcuk } \\
\text { olyanná.” }\end{array}$ \\
\hline Elvárások & $\begin{array}{l}\text {,Szerettem volna, ha pozitív benyomás alakul ki rólam. Igyekeztem } \\
\text { megtalálni az arany középutat, nem akartam túl szigorúnak, de túlzottan } \\
\text { engedékenynek sem látszani.” }\end{array}$ \\
\hline Probléma & $\begin{array}{l}\text {,Nagyon tartok a csendtöl és inkább beszélek helyette, de az utasításaim } \\
\text { nem eléggé egyértelmüek. Persze, így nem jutnak szóhoz a tanulók...” }\end{array}$ \\
\hline
\end{tabular}


Az izgalmat és az elvárásokat tetőzte a különféle problémák megjelenése az órán (fegyelmezetlenség, nehéz magyarázni, figyelni kell a kérdések egyértelmüségére stb.), amelyek a tanárjelöltek két alapvető kategóriába sorolhatóságát eredményezték. Mindezt jól mutatják az első óra utáni reflexiók. Az egyik csoport nagyon elégedett, sikerélményük volt, nem változtatnának semmit az óra felépítésén és energikusan, önbizalommal teli tekintenek a következő napok kihívásai elé: „Ha újra végig kellene csinálni /.../ semmit sem csinálnék másképp, hiszen minden úgy sikerült, ahogy elterveztem." A másik csoport kudarcnak érezte tevékenységét, semmi nem sikerült az órán, és ez félő, hogy a tanítási gyakorlat hátralévő részére is rányomja a bélyegét: „Az óra nagyon rosszul sikerült. Néhány szituációban nem tudok alkalmazkodni az osztály viselkedéséhez.”; „,Rá kellett jönnöm, hogy történnek váratlan dolgok az órán, amire nem lehet elöre felkészülni.". Ilyen esetekben is rendkívül hasznos volt a szeminárium, ahol a csoporttagokkal közösen elemeztük és tártuk fel a kudarcnak vélt órák okait, válaszokat, megoldásokat kerestünk a felmerült problémákra.

Általános vélekedés szerint az első nap rendkívülien megerőltető volt, mindenki a fáradtságra panaszkodott: „Óra után $\mathrm{kb}$. fél órával hihetetlenül fáradt voltam /.../ nem gondoltam volna, hogy ennyire fárasztó tud lenni egy óra megtartása.”; „A napom nagyon fárasztó volt /.../ a hangom rekedtessé vált, a kezem nagyon kiszáradt a krétaportól. Legközelebb kényelmesebb cipőt veszek fel, mert a lábam is elfáradt."

A tanítási gyakorlat a tanárjelöltek számára az érzelmi megpróbáltatások időszaka is volt, hiszen a tanítás egész embert kíván, a teljes személyiséget próbára teszi, és az esetleges negatív hatások befolyásolják a személyiséget is. Vagyis reflexiós korlátként jelennek meg az érzelmek (Kimmel, 2006), hiszen ahhoz, hogy szakszerüen és érdemben tudjuk elemezni tevékenységünket, fel kell dolgoznunk az órán, az iskolában történtek érzelmi aspektusait. Mindez változóan sikerült a hallgatóknak, de a gyakorlatkövető szeminárium számára rendkívülien tanulságosak a reflexiók, hiszen a következő szemináriumi csoportok számára újabb irányokat, elemzési szempontokat jelölnek ki.

Mit jelent azok számára a tanítás, a tanári munka, akiknek csalódás volt a tanítási gyakorlat és mély érzelmi nyomokat hagyott bennük az iskolákban eltöltött idő? Aggodalomra ad okot, hogy ezek a hallgatók soha nem fogják átélni a tanári pálya örömeit, nem tapasztalják meg a szépségeit, hiszen diplomájuk megszerzése után más területen kívánnak érvényesülni. Mindezek igazolására álljon itt néhány gondolat a hallgatóktól: „Mindig mosolygok és próbálok nagy lendülettel, energikusan nekivágni az órának, hátha ez hatással lesz a társaságra. De az óra végén mindig csalódok, hogy ennek sincs eredménye.”; „Volt, aki sminkelt, másik evett. Kértem, hogy hagyják abba. Mi mást tehet ilyenkor egy gyakorló tanár?"

Az előbbi nézetekkel ellentétes álláspontot képviselnek azok, akiknek sikerélményük volt és az iskolában, az órákon történtek érzelmi aspektusainak feldolgo- 
zásával új lendülettel állnak a kihívások elé: „A legnagyobb dicséret az volt, hogy az órám után az egyik tanuló odajött hozzám és azt mondta, hogy nagyon tetszett neki az óra, szerinte jó tanár lennék.”; „Nagy felüdülést jelentett számomra /.../ nem kellett fegyelmezéssel töltenem egyetlen percet sem. Ez persze nem azt jelenti, hogy az órák /.../ katonás rendben zajlottak."

A reflexiók alapján összegzésként megállapítható, hogy a tanárképzésben szükséges a reflektív pedagógia elemeit még inkább meghonosítani és szilárdabb alapokra helyezni, hiszen nagymértékben segítik a tanárjelöltek tanítási gyakorlatát, továbbá a későbbiekben a gyakorló tanári munka fejlesztéséhez is hozzájárulnak. A reflektív pedagógia tanításait követő szeminárium segítségével a hallgatók reflexiói a legalacsonyabb technikai szintről (mit tegyek?) a tevékenység összetett elemzése felé mozdulhatnak el (miért tettem? Honnan tudom, hogy így kellett tennem?). Bízom abban, hogy a tanárjelöltek a majdani gyakorló tanári tevékenységük elemzéséhez is megfelelő támpontokat kaptak a félév során, hiszen a pedagógus munkájának hatékonysága csak úgy fokozható, ha időnként megállunk, és kritikusan megvizsgáljuk tetteink tanulókra, szülőkre és önmagunkra gyakorolt hatásait, vagyis az önreflexiókat tevékenységünk korszerüsítésére és hatékonyabbá tételére használjuk.

\section{Irodalom}

Falus Iván (2001a): Gondolkodás és cselekvés a pedagógus tevékenységében. In: Báthory Zoltán és Falus Iván (szerk.): Tanulmányok a neveléstudomány köréböl. Osiris Kiadó, Budapest, 213-234.

Falus Iván (2001b): A gyakorlat pedagógiája. In: Golnhofer Erzsébet és Nahalka István (szerk.): A pedagógusok pedagógiája. Nemzeti Tankönyvkiadó, Budapest 15-26.

Falus Iván és Kimmel Magdolna (2003): A portfolió. Gondolat Kiadói Kör, Books in Print, Budapest.

Kimmel Magdolna (2002): A reflektív gyakorlat gyökerei. Pedagógusképzés, 3. sz. 120123.

Kimmel Magdolna (2006): A tanári reflexió korlátai. Pedagógusképzés, 3-4. sz. 35-49.

Sántha Kálmán (2007a): Kvalitatív módszerek alkalmazása a reflektív gondolkodás feltárásában. In: Falus Iván (szerk.): A tanárrá válás folyamata. Gondolat Kiadó, Budapest $177-243$.

Sántha Kálmán (2007b): A hatékonyság kulcsa: reflektivitás. In: Bábosik István és Torgyik Judit (szerk.): Pedagógusmesterség az Európai Unióban. Eötvös Kiadó, Budapest 293-314.

Schön, D. A. (1983): The reflective practitioner. How professionals think in action. Temple Smith, London.

Schön, D. A. (1987): Educating the Reflective Practitioner. Jossey-Bass, San Francisco.

Schratz, M. (1998): Unterrichtforschung. Fernuniversität in Hagen. Fachbereich Kulturund Sozialwissenschaften, Hagen. 
Szabó László Tamás (1999): A reflektív tanítás. Educatio, 2-3. sz. 500-506.

Szabó László Tamás (2000): A „reflektív paradigma” neveléstudományi nézőpontból. Egy fogalom színe és visszája. Pedagógusképzés, 133-140.

Szivák Judit (2003): A reflektív gondolkodás fejlesztése. Gondolat Kiadói Kör, Books in Print, Budapest.

Werner, J. és Meyer H. (2002): Didaktische Modelle. Cornelsen Scriptor, Berlin. 